\title{
Author Correction: Insulin-producing organoids engineered from islet and amniotic epithelial cells to treat diabetes
}

\author{
Fanny Lebreton (D, Vanessa Lavallard (1), Kevin Bellofatto, Romain Bonnet, Charles H. Wassmer, Lisa Perez, \\ Vakhtang Kalandadze, Antonia Follenzi (D), Michel Boulvain, Julie Kerr-Conte, David J. Goodman, \\ Domenico Bosco (1), Thierry Berney (i) \& Ekaterine Berishvili (i)
}

Correction to: Nature Communications https://doi.org/10.1038/s41467-019-12472-3, published online 3 October 2019.

In the original version of this Article the ethical registration number permitting collection of amniotic membranes in the Human samples subsection of the "Methods" section was mis-cited as 2017-00101. The correct number refers to the pre-Basec study PB_201700101, which is not listed in the Register of Research Projects in Switzerland (RAPS). The old reference number of this study is $14-273$ and can be found in a list of protocols submitted before 2015 (https://www.ge.ch/document/liste-protocoles-soumis-2015).

This has been corrected in both the PDF and HTML versions of the Article.

Published online: 09 October 2020

\footnotetext{
(C) Open Access This article is licensed under a Creative Commons Attribution 4.0 International License, which permits use, sharing, adaptation, distribution and reproduction in any medium or format, as long as you give appropriate credit to the original author(s) and the source, provide a link to the Creative Commons license, and indicate if changes were made. The images or other third party material in this article are included in the article's Creative Commons license, unless indicated otherwise in a credit line to the material. If material is not included in the article's Creative Commons license and your intended use is not permitted by statutory regulation or exceeds the permitted use, you will need to obtain permission directly from the copyright holder. To view a copy of this license, visit http://creativecommons.org/licenses/by/4.0/.
}

(c) The Author(s) 2020 